Check for updates

Cite this: J. Anal. At. Spectrom., 2021, 36,1512

\title{
Correlation of $\mu$ XRF and LA-ICP-MS in the analysis of a human bone-cartilage sample $\uparrow$
}

\author{
Anna Turyanskaya, (iD *a Stefan Smetaczek, (D) ${ }^{\mathrm{b}}$ Vanessa Pichler, (iD) ${ }^{\mathrm{a}}$ \\ Mirjam Rauwolf, (D) a Lukas Perneczky, (D) a Andreas Roschger, (D) Paul Roschger, ${ }^{d}$ \\ Peter Wobrauschek, (D) ${ }^{a}$ Andreas Limbeck (D) $^{b}$ and Christina Streli (iD)
}

\begin{abstract}
Determining the local distribution of major, minor and trace elements in biological tissues provides fundamental information on the chemical composition and often allows conclusions on the underlying biochemical mechanisms. Within this project we aimed for the elemental characterization of a complex biological sample, a human femoral head, which includes both hard (bone and mineralized cartilage) and soft tissue (hyaline cartilage). Two elemental imaging methods were employed - microbeam X-ray fluorescence spectrometry ( $\mu \mathrm{XRF}$ ) and laser ablation inductively coupled plasma mass spectrometry (LAICP-MS). $\mu$ XRF and LA-ICP-MS are widely used for chemical analysis in various applications. While bone consists mostly of mineralized material and its elemental composition is in the focus of investigation (both in health and disease), hyaline cartilage is primarily composed of organic molecules such as glycosaminoglycans, proteoglycans, collagen, and its elemental content is not well studied. In this proofof-principle study, $\mu$ XRF was followed by LA-ICP-MS on the very same sample and region. The measurements resulted in the elemental maps of bone, as well as a cartilaginous area of the sample (including the tidemark - interface between calcified and hyaline cartilage). In addition to the spatial distribution of elements, we also obtained quantitative information by using matrix-matched standards.
\end{abstract}

Received 6th January 2021

Accepted 4th May 2021

DOI: $10.1039 / \mathrm{d} 1 \mathrm{ja} 00007 \mathrm{a}$

rsc.li/jaas

\section{Introduction}

Investigation of biological tissues often requires obtaining comprehensive chemical elemental information. Recent developments in elemental imaging techniques allow visualisation of elemental distributions on different levels of organization from model organisms ${ }^{1}$ to tissues ${ }^{2,3}$ and single cells. ${ }^{4}$

Bone, due to its inorganic components - it contains a mineral phase (hydroxyapatite), is a tissue especially suitable for elemental analysis. Furthermore, the sample preparation and sample handling requirements are often simpler compared to other biological tissues as there is usually no need for cryopreservation and thicker samples are self-supporting, which reduces the need for a backing material. The topics of investigation which were successfully addressed using elemental

${ }^{a}$ Atominstitut, TU Wien, Stadionallee 2, 1020 Vienna, Austria. E-mail: anna. turyanskaya@tuwien.ac.at

${ }^{b}$ Institute of Chemical Technologies and Analytics, TU Wien, Getreidemarkt 9/164, 1060 Vienna, Austria

'Paris-Lodron-University of Salzburg, Department of Chemistry and Physics of Materials, Jakob-Haringer-Strasse 2a, 5020 Salzburg, Austria

${ }^{d}$ Ludwig Boltzmann Institute of Osteology at the Hanusch Hospital of OEGK and AUVA Trauma Centre Meidling, 1st Medical Department Hanusch Hospital, Heinrich-CollinStrasse 30, 1140 Vienna, Austria

$\dagger$ Electronic supplementary information (ESI) available. See DOI: 10.1039/d1ja00007a imaging in bone range from bone architecture, ${ }^{5}$ content of specific trace elements in various conditions - i.e. osteosarcoma, ${ }^{3}$ to investigation of novel orthopaedic materials. ${ }^{6}$

Within joints, bone is covered by articular cartilage - which, based on the degree of mineralization, is subdivided into mineralized and hyaline cartilage. The interface between mineralized and hyaline cartilage is called tidemark. The mineralized tissue and especially the tidemark are intensely studied. It is known that the tidemark is the site of metal accumulation, e.g. zinc and lead, and several elemental imaging experiments have been devoted to this topic on animal or human cartilage samples. ${ }^{7-10}$ Compared to bone, hyaline cartilage is substantially less investigated in terms of elemental composition. There are some imaging approaches to visualize hyaline cartilage, such as fluorescent microscopy, contrastenhanced scanning electron microscopy, computed tomography and magnetic resonance imaging, ${ }^{11,12}$ however, the imaging experiments involving the elemental distribution are scarce.

Therefore, in our proof-of-principle experiment we tested the analytical capabilities of two elemental imaging techniques within one sample - the cuts of a femoral head which included both bone and cartilage tissues. For analysis we employed the methods of microbeam X-ray fluorescence analysis ( $\mu \mathrm{XRF}$ ) and laser ablation inductively coupled plasma mass spectrometry (LA-ICP-MS). 


\section{$\mu \mathrm{XRF}$}

The method is based on the excitation of the sample by X-rays, resulting in the emission of characteristic radiation by each particular element, provided that the excitation energy is above the absorption edge of the element of interest (the measurable range generally spans from sodium to uranium, and can depend on the technical characteristics of the spectrometer and experimental parameters chosen). The fluorescence radiation emitted from the sample is registered by an energy dispersive detector - and the information about various elements present in the sample is obtained simultaneously. The resultant characteristic spectra are deconvoluted using dedicated software: spectral overlaps and artefacts are considered, and background is subtracted in order to extract information about elements of interest. In imaging experiments a sample is raster scanned, yielding elemental maps. The spatial resolution of such a scan/ map depends on the size of the X-ray beam (as well as on the energy of the exciting X-rays and the emitted characteristic X-ray of the sample element). In the case of $\mu \mathrm{XRF}$, the beam is focused to a few tens of micrometres, so the resolution is in the similar range. The technique is non-destructive, and hence the sample can be further analysed. The technique is often used for qualitative imaging; nonetheless, quantification is possible; e.g. by use of matrix-matched standards.

\section{LA-ICP-MS}

In this technique, a short-pulsed, high-power laser beam is focused onto the sample surface, leading to the ablation of a finite volume of sample material. The resulting solid aerosol is transported by a carrier gas stream into an inductively coupled plasma, where the sample is atomized and ionized. In a final step, the formed ions are introduced to a mass spectrometer, usually equipped with a quadrupole mass analyser. LA-ICP-MS provides major, minor, and trace element information with a wide elemental coverage. It also offers the possibility to perform elemental mapping with high spatial resolution (mostly determined by the laser beam diameter) in the micrometre range. Since LA-ICP-MS suffers from sample-dependent ablation behaviour and elemental fractionation, reliable signal quantification of such imaging experiments is challenging. To overcome these issues, matrix-matched calibration standards in combination with an internal standard correction are generally used. ${ }^{13}$

Both $\mu$ XRF and LA-ICP-MS are well-established in the analysis of biological samples. ${ }^{\mathbf{1 4 - 1 6}}$ As both techniques provide elemental information, there exist some comparative studies. Davies et al. compared synchrotron-induced $\mu$ XRF and LA-ICPMS applied to consecutive slices of neurological tissue (mouse brain) for imaging and quantification of metals. ${ }^{17}$ Few studies have been published on the sequential use of both techniques on the same biological sample. Gholap et al. used laboratory $\mu \mathrm{XRF}$ and then LA-ICP-MS for mapping the same thin section of Daphnia magna $;^{1}$ and Müller et al. used triple quadrupole LAICP-MS (LA-ICP-TQMS) preceded by $\mu \mathrm{XRF}$ on the same murine liver section. ${ }^{\mathbf{1 8}}$

In our study we applied $\mu$ XRF followed by LA-ICP-MS in a partially complementary manner to obtain comprehensive information on the distribution of the elements within tissues. The objectives of the study included: characterisation of bone and cartilage tissues in terms of elemental distribution, collection of quantitative information for the detected elements in those tissues, and comparison of the two elemental imaging methods.

The project is a part of ongoing effort at TU Wien to advance correlation between imaging methods in biomedical applications. ${ }^{19-21}$

\section{Materials and methods}

\section{(1) Sample preparation}

A femoral head biopsy sample from a female patient (93 years old), previously collected for a study investigating the relation between bone quality and homocysteine levels (high homocysteine level group) ${ }^{22}$ was used in the present study. All studyrelated procedures were approved and supervised by the local ethical committee of the AUVA Trauma Centre Meidling, Vienna, Austria, following the Declaration of Helsinki (DoH). The patient provided written consent for anonymized outcomes to be further used in scientific examinations.

The undecalcified biopsy was fixed in $70 \%$ ethanol, dehydrated through a graded ethanol series, and embedded in PMMA (polymethylmethacrylate). Thin sections were prepared out of a single PMMA block. $15 \mu \mathrm{m}$ slice was cut using a microtome (LEICA SM2500; Leica Microsystems $\mathrm{GmbH}$, Wetzlar, Germany); while $41 \mu \mathrm{m}$ was obtained by grinding with sandpaper (first abrasive grit size of 1200 up to the desired thickness then abrasive grit size 2400) and polishing using polycrystalline diamond spray ( $3 \mu \mathrm{m}$ and $1 \mu \mathrm{m})$. Further details on sample preparation can be found elsewhere. ${ }^{23}$ The samples were prepared in such a way as to include both bone and articular cartilage tissues. Fig. 1 shows the morphology of the

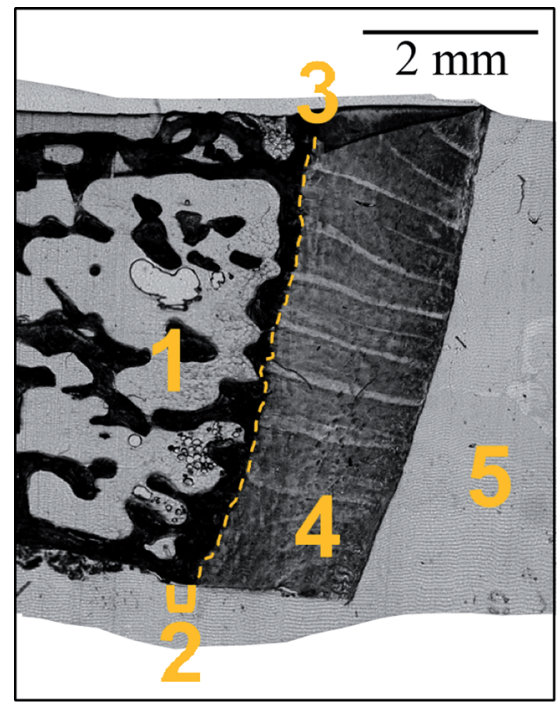

Fig. 1 Micrograph (transmitted light microscopy) of an exemplary sample: 1 - trabecular bone (black); 2 - subchondral cortical bone and mineralized cartilage (black); 3 - tidemark (dashed line); 4 - hyaline cartilage; 5 - PMMA outside of the tissue sample. 
sample. Two slices of thickness 15 and $41 \mu \mathrm{m}$ were used for the imaging experiments.

\section{(2) $\mu \mathrm{XRF}$ measurements, data analysis and quantification}

An in-house-built $\mu$ XRF setup at the Atominstitut, TU Wien, was employed non-confocally (i.e. only one focusing optic, a polycapillary lens - between X-ray tube and sample). More information on the setup can be found $i^{6,21,24}$ (see also Fig. S1 in $\mathrm{ESI} \dagger)$.

For the measurements, the samples were sandwiched between acrylic glass frames and attached to a sample holder, which facilitated direct measurement on the sections and eliminated unwanted fluorescent/scattering contributions of backing materials. The samples were positioned vertically in the spectrometer chamber; the standard geometry $45^{\circ}$ between the incident radiation beam and the sample, and $90^{\circ}$ between the incident beam and the detector was maintained. For these measurements, a Rh-anode low power X-ray tube was used; the tube voltage and current were set to $50 \mathrm{kV}$ and $0.4 \mathrm{~mA}$, respectively. The measurement conditions were: $50 \mu \mathrm{m}$ step size, $60 \mathrm{~s}$ acquisition time per spot (real time), in vacuum ( $<3 \mathrm{mbar})$. The step size was chosen due to the estimated beam size of $50 \mu \mathrm{m}$ (at $8 \mathrm{keV}$ ). Deconvolution of the spectra was performed using the QXAS-AXIL software package. ${ }^{25}$ The original elemental maps were created as text files using the software LP-map ${ }^{26}$ and processed (negative values zeroed for correct representation) and plotted with ImageJ (version 1.50b). ${ }^{27}$ The XRF data were dead time corrected. The XRF maps were quantified using the sensitivity values obtained via the measurements of IAEA Animal Bone (H-5) certified reference material, the details can be found in the Master's thesis of V. Pichler. ${ }^{28}$ The sensitivity values of the elements for which data was not available sulphur and potassium, were derived by interpolation. The thickness of the cuts was not considered in quantification. The elemental maps, showing the whole scanned area - source images, are included in the ESI. $\dagger$

For easier comparison and correlation of XRF and LA-ICP-MS data, further analysis by ImageLab (v. 2.99 Epina $\mathrm{GmbH}$, Pressbaum, Austria) was performed (see also below in (3) LAICP-MS measurements and data analysis) - and the resultant elemental maps, showing the very same area scanned by both techniques are included in the current manuscript. The original $\mu \mathrm{XRF}$ maps can be found in the ESI. $\dagger$

Fluorescence sum spectra were plotted with Origin (version OriginPro 2015, OriginLab Corporation, Northampton, MA, USA).

\section{(3) LA-ICP-MS measurements and data analysis}

A NWR213 laser ablation system (ESI, Fremont, CA, USA) equipped with a frequency quintupled $213 \mathrm{~nm}$ Nd:YAG laser and a fast-washout ablation cell, always held above the actual ablation site, was used for all shown LA-ICP-MS experiments. The device was coupled to an iCAP Q quadrupole ICP-MS instrument (Thermo Fisher Scientific, Bremen, Germany) using PTFE tubing (inner diameter $2 \mathrm{~mm}$ ). A schematic representation of a general LA-ICP-MS setup is shown on Fig. S1 in
ESI. $\dagger$ Helium was used as carrier gas for cell washout, which was mixed with Ar make-up gas upon introduction into the plasma. For data acquisition, Qtegra software provided by the manufacturer of the instrument was used. The tune settings of the MS instrumentation were optimized for maximum ${ }^{115}$ In signal prior to each experiment using a NIST 612 trace metal in glass standard (National Institute of Standards and Technology, Gaithersberg, MD, USA). Additionally, the oxide ratio was monitored by the ${ }^{140} \mathrm{Ce}^{16} \mathrm{O} /{ }^{140} \mathrm{Ce}$ ratio, which was below $2.0 \%$ for all experiments. To reduce the influence of polyatomic interferences, kinetic energy discrimination (KED) mode utilizing a collision cell containing a mixture of helium with $7 \%$ hydrogen was used. A list of potential polyatomic interferences is given in Table $\mathrm{S} 2 . \dagger$

Two-dimensional elemental distribution maps were created using line scan ablation patterns with adjoining lines. In case of the $15 \mu \mathrm{m}$ slice, an additional pre-ablation step using a similar pattern and reduced laser fluence $\left(4.6 \mathrm{~J} \mathrm{~cm}^{-2}\right)$ was performed prior to the measurement, removing potential surface contaminations. For image processing, the software ImageLab (v. 2.99 Epina $\mathrm{GmbH}$, Pressbaum, Austria) was used. A pixel size of $25 \mu \mathrm{m}$ was chosen for the distribution maps, which corresponds to the used laser beam diameter. For plotting the images, interpolated colour surfaces were employed. To evaluate the agreement between obtained maps with the corresponding $\mu \mathrm{XRF}$ images, a correlation analysis was performed using the correlation feature integrated in the software. Detailed information about the used LA-ICP-MS parameters is given in Table 1.

Taking into account, that the samples include tissues with significant variations in chemical composition (mineralized tissues and hyaline cartilage), two different standard materials were used for the quantification. While analytes predominately expected in the calcified area ( $\mathrm{Ca}, \mathrm{Mg}, \mathrm{Na}, \mathrm{P}, \mathrm{Zn}$ ) were quantified using an IAEA Animal Bone ( $\mathrm{H}-5)$ certified reference material,

Table 1 Instrumental parameters LA-ICP-MS imaging experiments

\begin{tabular}{ll}
\hline & ESI NWR213 \\
\hline Average fluence & $11.4 \mathrm{~J} \mathrm{~cm}^{-2}$ \\
Laser diameter & $25 \mu \mathrm{m}$ \\
Scan speed & $75 \mu \mathrm{m} \mathrm{s}^{-1}$ \\
Repetition rate & $20 \mathrm{~Hz}$ \\
Carrier gas flow (He) & $0.65 \mathrm{~min}^{-1}$ \\
Make-up gas flow (Ar) & $0.81 \mathrm{~min}^{-1}$ \\
\hline & Thermo iCAP Q \\
\hline RF power & $1550 \mathrm{~W}$ \\
Plasma gas flow (Ar) & $141 \mathrm{~min}^{-1}$ \\
Auxiliary gas flow (Ar) & $0.81 \mathrm{~min}^{-1}$ \\
Collision gas flow (He $\left.+7 \% \mathrm{H}_{2}\right)$ & $3 \mathrm{ml} \mathrm{min}{ }^{-1}$ \\
Kinetic energy barrier & $3 \mathrm{~V}$ \\
Dwell time per isotope & $10 \mathrm{~ms}$ \\
Cones & $\mathrm{Ni}$ \\
Measured isotopes & ${ }^{23} \mathrm{Na},{ }^{24} \mathrm{Mg},{ }^{31} \mathrm{P},{ }^{34} \mathrm{~S},{ }^{39} \mathrm{~K},{ }^{42} \mathrm{Ca}$, \\
& ${ }^{50} \mathrm{Cr},{ }^{55} \mathrm{Mn},{ }^{56} \mathrm{Fe},{ }^{59} \mathrm{Co},{ }^{64} \mathrm{Zn}$
\end{tabular}


a self-made porcine cartilage standard was used for analytes expected in the hyaline cartilage region $(\mathrm{K}, \mathrm{S})$. The porcine cartilage standard was characterized via conventional ICP-MS analysis, resulting in $\mathrm{K}$ and $\mathrm{S}$ contents of $2.46 \mathrm{mg} \mathrm{kg} \mathrm{kg}^{-1} \pm$ $0.19 \mathrm{mg} \mathrm{kg}^{-1}(\bar{x} \pm s ; n=3)$ and $11.1 \mathrm{mg} \mathrm{kg}^{-1} \pm 1.2 \mathrm{mg} \mathrm{kg}^{-1}(\bar{x} \pm$ $s ; n=3)$, respectively. The sample was digested in a $1 / 1$ volumetric mixture of $\mathrm{HNO}_{3}(65 \mathrm{w} / \mathrm{w} \%)$ and $\mathrm{H}_{2} \mathrm{O}_{2}(30 \mathrm{w} / \mathrm{w} \%)$. An iCAP Q ICP-MS instrument (Thermo Fisher Scientific, Bremen, Germany) was used for the analysis. Detailed information about the standard characterization can be found in the ESI. $\dagger$

\section{$\mu \mathrm{XRF}$}
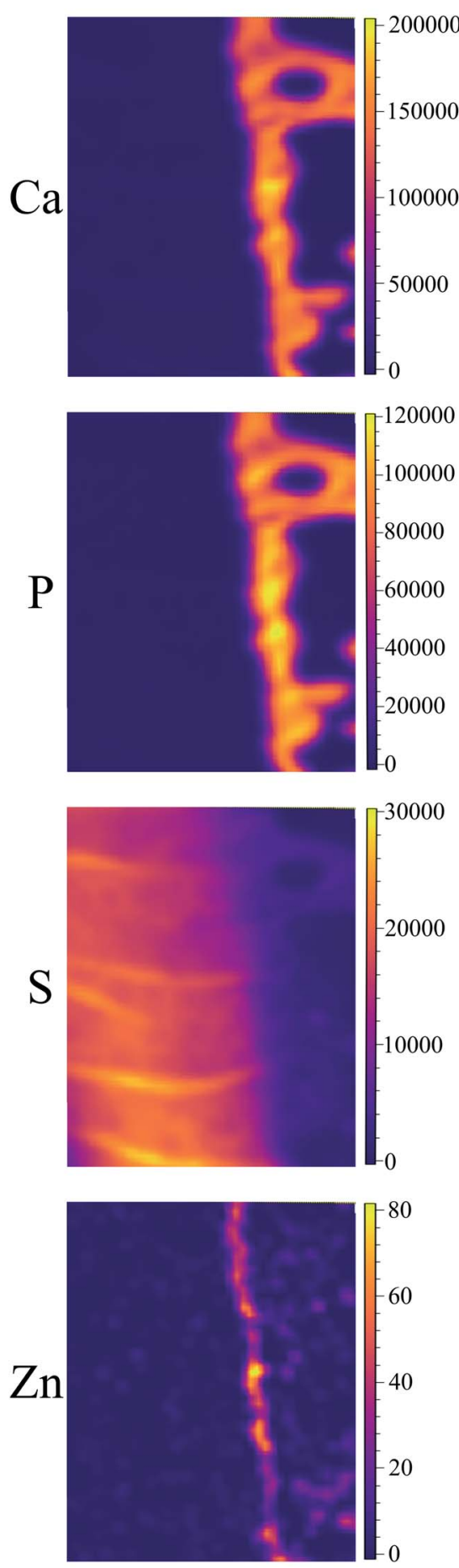

\section{LA-ICP-MS}
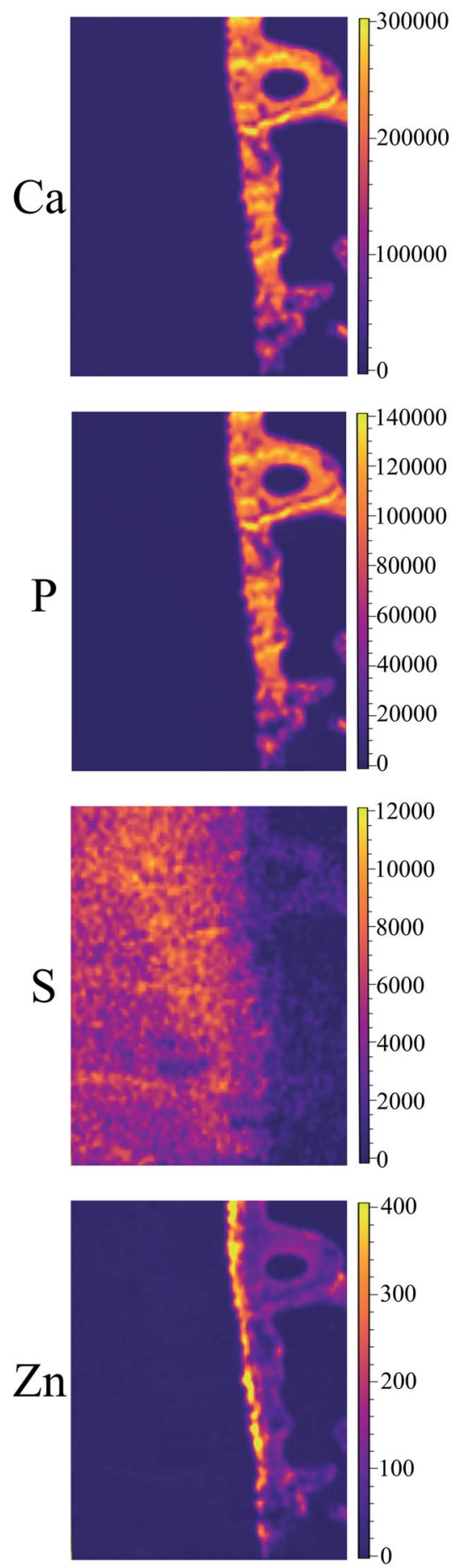
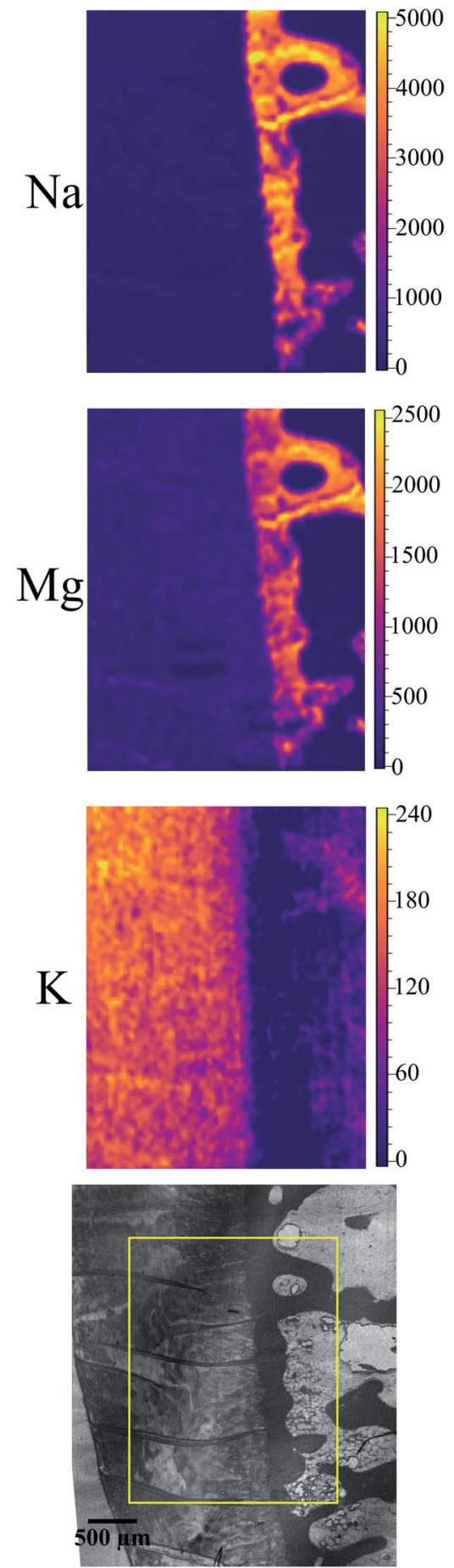

Fig. $215 \mu \mathrm{m}$ slice: elemental maps obtained by $\mu$ XRF and LA-ICP-MS. The micrograph (transmitted light microscopy) in the low right corner shows the scanned region (yellow rectangle). The units for both $\mu$ XRF and LA-ICP-MS maps are $\mu g^{-1}$. Please note, that $S \mu X R F$ map is subject to fitting artifact within mineralized tissue (no $S$ actually detected), detailed explanation is provided in the text. 
The measurement of the standards was performed directly before the imaging experiments using identical instrument and laser settings. Each standard was analysed four times using laser patterns consisting of adjacent line scans. The investigated area was $0.35 \mathrm{~mm}^{2}$ per laser pattern. For further data processing, the mean values of the four-fold analysis were used. To remove potential surface contaminations, a pre-ablation step was performed before the measurements.

\section{Results and discussion}

Local elemental distributions were obtained from the measurement areas, which were chosen such as to include bone, articular cartilage tissue and the metabolically active area of tidemark - the interface between calcified and non-calcified cartilage; the elemental maps of $15 \mu \mathrm{m}$ and $41 \mu \mathrm{m}$ cuts are shown on Fig. 2 and 3, respectively. These figures show the very same area within each slice imaged by $\mu \mathrm{XRF}$ and LA-ICP-MS (further details are provided in the text below).

\section{$\mu \mathrm{XRF}$}

The sum spectra (generated by adding spectra from each measured point) obtained from $\mu \mathrm{XRF}$ scans of two cuts are shown in Fig. 4. High content of $\mathrm{Ca}$ and $\mathrm{P}$ corresponds to the bone and calcified cartilage area, while high $\mathrm{S}$ peak can be attributed to the hyaline cartilage. $\mathrm{Zn}, \mathrm{Pb}$ and $\mathrm{Sr}$ are expected to be found in the sample ( $\mathrm{Zn}$ in both cartilage and bone, accumulation of $\mathrm{Zn}$ and $\mathrm{Pb}$ in tidemark, $\mathrm{Sr}$ - in bone), although $\mathrm{Pb}$ and $\mathrm{Sr}$ peaks are hardly discernible, therefore, these metals were excluded from further analysis. Fe, although normally present in tissues (e.g. from blood), can also be introduced in the sample by the cutting equipment, therefore, Fe, Co, as well as $\mathrm{Ti}$ and $\mathrm{Cr}$ (only found in the $41 \mu \mathrm{m}$ cut) were considered contaminations. Interestingly, in the sum spectrum of $41 \mu \mathrm{m}$ cut, peak of $\mathrm{K}$ can be recognised on the left shoulder of $\mathrm{Ca}-\mathrm{K} \alpha$ peak.

Fig. 2 and 3 show segments of the scans performed on the 15 $\mu \mathrm{m}$ cut and $41 \mu \mathrm{m}$ cut, respectively, to match the areas imaged by both methods. The whole $\mu$ XRF scans are included in the ESI (Fig. S2 and S3†). A detailed description of the $\mu \mathrm{XRF}$ results provided below is based on the original $\mu \mathrm{XRF}$ maps. Please note that the values discussed further in this section originate from the Tables S3 and S4 in the ESI. $\dagger$

$\mu \mathrm{XRF}$ results for $15 \mu \mathrm{m}$ slice (Fig. 2 , left column). Ca and $\mathrm{P}$ content is naturally high in the calcified tissues (bone and mineralized cartilage) with average concentrations of $120 \mathrm{mg}$ $\mathrm{g}^{-1}$ and $80 \mathrm{mg} \mathrm{g}^{-1}$, respectively. Ca is also present throughout the hyaline cartilage, although not visible on the map due to the colour scheme scaling. Within the cartilage, Ca content is overall rather homogeneous in the middle cartilage layer - 1.5$2.5 \mathrm{mg} \mathrm{g}^{-1}$, and slightly lower in superficial layer, $1-1.5 \mathrm{mg} \mathrm{g}^{-1}$. In the vicinity of the tidemark Ca concentration rises sharply, and within tidemark $\mathrm{Ca}$ mean values are similar to bone around $100 \mathrm{mg} \mathrm{g}^{-1}$.

Sulphur is present exclusively in the hyaline cartilage with an average concentration of $c a .17 \mathrm{mg} \mathrm{g}^{-1}$. It should be noted that the presence of $\mathrm{S}$ (values $\leq 4 \mathrm{mg} \mathrm{g}^{-1}$ ) within calcified tissues occurs due to a spectral artifact: the high Ca signal causes an escape peak of $\mathrm{Ca}-\mathrm{K} \beta$ line at $2.27 \mathrm{keV}$. This artificial peak has similar energy to $\mathrm{S}(2.3 \mathrm{keV})$, therefore fitting software misrelates the signal. The line structures, which can be seen within the hyaline cartilage in microscopy picture and also in the $\mathrm{S}$ map correspond to the folds on the sample surface. The concentrations of $\mathrm{S}$ and $\mathrm{Ca}$ in the folds are nearly two times higher than in the surrounding tissue.

$\mathrm{Zn}$ is present in bone and, in higher content in the tidemark zone. The estimated mean $\mathrm{Zn}$ concentration is $15 \mu \mathrm{g} \mathrm{g}^{-1}$ in bone and $50 \mu \mathrm{g} \mathrm{g}^{-1}$ in tidemark.

$\mu$ XRF results for $41 \mu \mathrm{m}$ slice (Fig. 3 , left column). Similar to the $15 \mu \mathrm{m}$ slice, there are high concentrations of $\mathrm{Ca}$ and $\mathrm{P}$ in the calcified tissues quantified to $190 \mathrm{mg} \mathrm{g}^{-1}$ and $100 \mathrm{mg} \mathrm{g}^{-1}$, respectively (average values over the calcification region). $\mathrm{Ca}$ is also confirmed in every scan point within hyaline cartilage, its content ranges from $2-3 \mathrm{mg} \mathrm{g}^{-1}$ in middle layer to up to $160 \mathrm{mg}$ $\mathrm{g}^{-1}$ in the tidemark zone.

Average $\mathrm{S}$ content in hyaline cartilage is around $27 \mathrm{mg} \mathrm{g}^{-1}$. The maps are subject to the same fitting problem for $S$ in the presence of high Ca content as described above for the $15 \mu \mathrm{m}$ slice. However, unlike the $15 \mu \mathrm{m}$ slice, $\mathrm{S}$ distribution was confirmed in the voids of trabecular bone, its origin remains unknown.

$\mathrm{Zn}$ is detected in bone, as well as in tidemark, where the concentration reaches $150-200 \mu \mathrm{g} \mathrm{g}^{-1}$. When comparing $\mathrm{Zn}$ XRF maps of the two slices, it can be seen that overall a more distinct Zn distribution was obtained for the thicker sample. However, the differentiation between bone and tidemark in the $41 \mu \mathrm{m}$ cut is not as clear as in $15 \mu \mathrm{m}$ slice. This can be understood considering that the theoretical information depth for $\mathrm{Zn}$ is about $98 \mu \mathrm{m}$. Therefore, in both cuts the signal from the entire sample thickness is obtained - albeit stronger in $41 \mu \mathrm{m}$ slice. In the thicker sample the information depth contributes also to the smearing effect for such a thin structure as tidemark, making tidemark in $41 \mu \mathrm{m}$ sample less pronounced than in the $15 \mu \mathrm{m}$ cut.

$\mathrm{K}$ is present in the hyaline cartilage of the $41 \mu \mathrm{m}$ slice, and there is a clear separated peak of $\mathrm{K}$ in corresponding spectra. The average $\mathrm{K}$ concentration in hyaline cartilage is $1.3 \mathrm{mg} \mathrm{g}^{-1}$. The $\mathrm{K}$ map seems to exhibit a higher $\mathrm{K}$ signal in the calcified zone, however in reality we are unable to confirm this element in mineralized tissue. This effect is caused again by intense $\mathrm{Ca}$ signal, in this case false-positive fitting of $\mathrm{K}$ occurs in tail of high Ca-K $\alpha$ peak.

For the interpretation of the results, it is important to note, that in the $\mu \mathrm{XRF}$ maps the depth resolution is elementdependent, and (in case of thin sections discussed in present paper) often is the representation of the signal from the entire sample thickness. In cortical bone, for example, it can be estimated as $9 \mu \mathrm{m}$ for P; $39 \mu \mathrm{m}$ for Ca and $98 \mu \mathrm{m}$ for $\mathrm{Zn}$, using the mass attenuation coefficients for cortical bone $(\mu / \rho)^{29}$ and the theoretical density for cortical bone of $1.92 \mathrm{~g} \mathrm{~cm}^{-3} \cdot{ }^{30}$ This is the reason why maximum $\mathrm{Ca}$ value in $41 \mu \mathrm{m}$ slice is about $50 \%$ higher than in the $15 \mu \mathrm{m}$ slice. Further, the information depth will be different for bone and hyaline cartilage, as it depends 


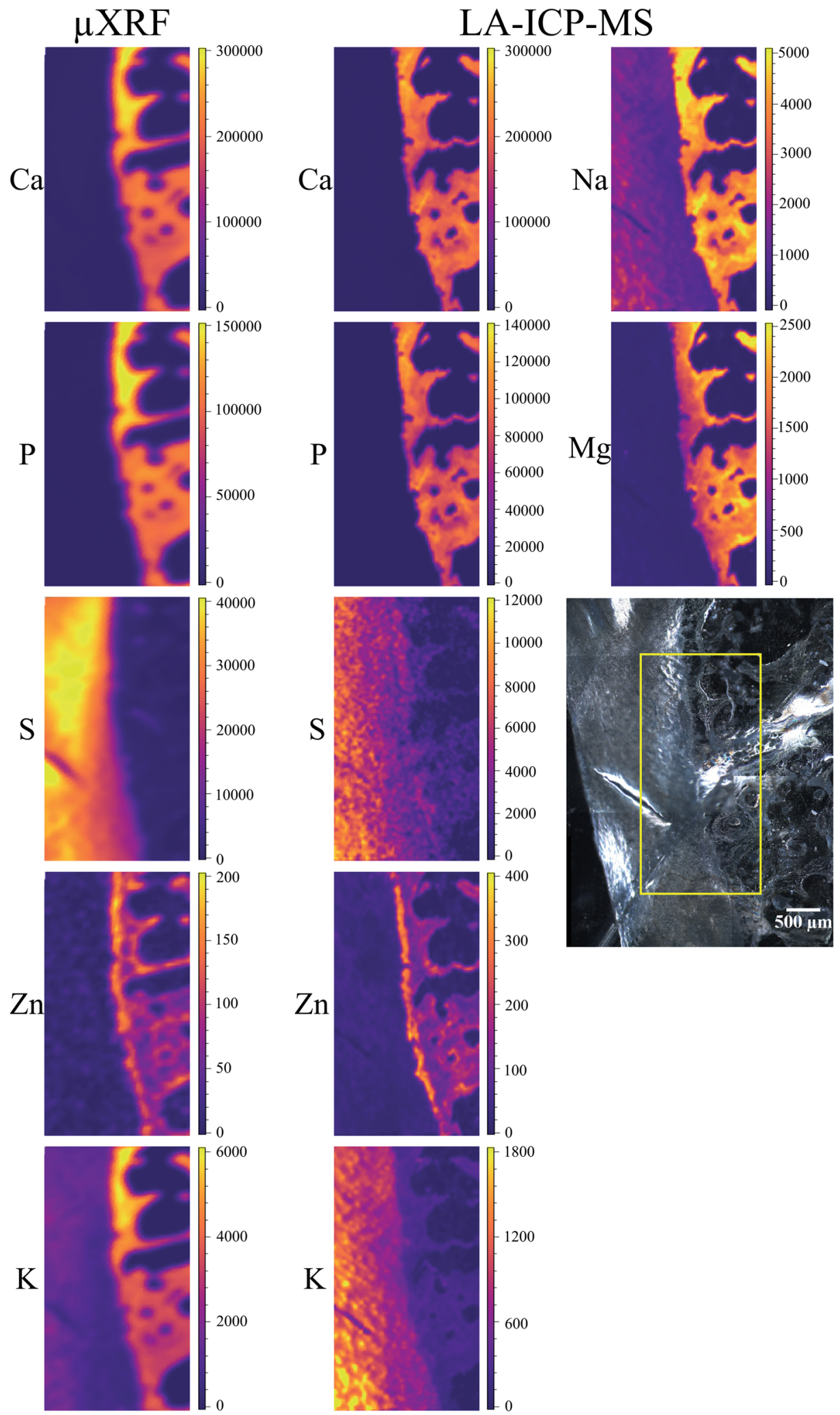

Fig. $341 \mu \mathrm{m}$ slice: elemental maps obtained by $\mu$ XRF and LA-ICP-MS. The micrograph shows the scanned region (yellow rectangle). The units for both $\mu$ XRF and LA-ICP-MS maps are $\mu \mathrm{g} \mathrm{g}^{-1}$. Please note, that $K \mu$ XRF map is subject to fitting artifact within mineralized tissue (no $K$ actually detected), detailed explanation is provided in the text.

strongly on the actual material composition. An approximation for the information depth values in cartilage can be obtained using the mass attenuation coefficients for soft tissue ${ }^{29}$ and the theoretical density for cartilage of $1.1 \mathrm{~g} \mathrm{~cm}^{-3}$ (ref. 30) as $16 \mu \mathrm{m}$ for P, $24 \mu \mathrm{m}$ for S, $50 \mu \mathrm{m}$ for K, $111 \mu \mathrm{m}$ for Ca and $872 \mu \mathrm{m}$ for $\mathrm{Zn}$. Quantification of cartilaginous zone by using IAEA Animal Bone 

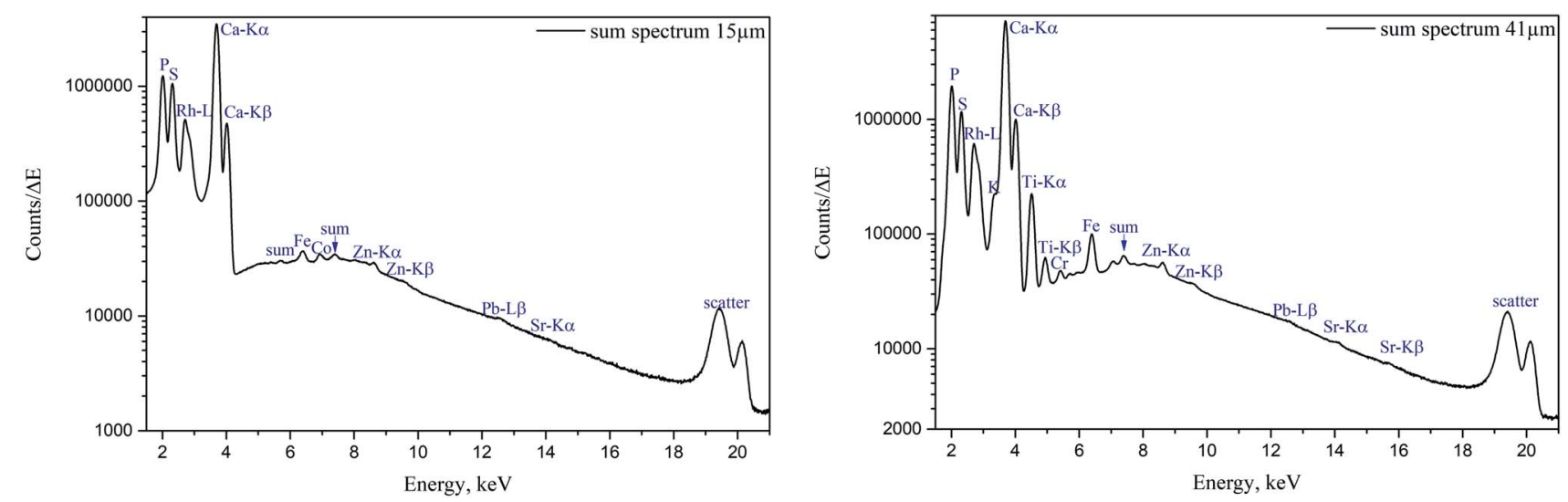

Fig. $4 \mu \mathrm{XRF}$ sum spectra of human femoral head sample; left $-15 \mu \mathrm{m}$ cut, right $-41 \mu \mathrm{m}$ cut.

(H-5) certified reference material (for $\mu \mathrm{XRF}$, see Materials and methods) is, therefore, not optimal. Unfortunately, cartilage certified reference material is not commercially available, and, thus, a well-characterized homogenous standard material (optionally doped with specific elements) will be beneficial in future measurements.

\section{LA-ICP-MS}

Major elements ( $\mathrm{Ca}, \mathrm{Mg}, \mathrm{Na}, \mathrm{K}, \mathrm{P}, \mathrm{S})$ as well as minor/trace elements (Co, Cr, Fe, Mn, $\mathrm{Zn}$ ) expected to be found in a sample were included in the LA-ICP-MS analysis. Although C is measurable with ICP-MS, it was excluded from the analysis since the C-rich embedding medium would falsify the analysis. For each analyte, one isotope was chosen using absence of potential (isobaric and polyatomic) interferences as well as natural abundance as selection criteria. We assume that the information depth of the LA-ICP-MS measurements is about 5 $\mu \mathrm{m}$, it is similar for both slices independently of their thickness, and only varies among different histological areas, i.e. mineralized tissues and hyaline cartilage.

${ }^{50} \mathrm{Cr}$ and ${ }^{55} \mathrm{Mn}$ did not provide sufficient signal-to-noise ratios for the generation of elemental maps and were therefore excluded from further analysis. ${ }^{56} \mathrm{Fe}$ and ${ }^{59} \mathrm{Co}$ show significant signal intensities in some sample areas, however, since they most likely originate from contaminations due to sample preparation they were excluded from further analysis as well. The elemental maps of the remaining analytes were quantified via external calibration using the measured IAEA Animal Bone (H-5) certified reference material as well as the self-made porcine cartilage standard. To keep matrix effects as small as possible, those analytes predominately in the calcified area $\left({ }^{42} \mathrm{Ca},{ }^{24} \mathrm{Mg},{ }^{23} \mathrm{Na},{ }^{31} \mathrm{P},{ }^{64} \mathrm{Zn}\right)$ were quantified using the bone standard, while the cartilage standard was used for those analytes predominately in the hyaline cartilage area $\left({ }^{34} \mathrm{~S},{ }^{39} \mathrm{~K}\right)$. This means that the analysis is not perfectly matrix-matched for the tissue in which the analyte shows lower concentration (e.g. Ca in hyaline cartilage tissue). However, since the presence of most elements is rather limited to one kind of tissue (e.g. Ca in mineralized tissue), the resulting error is hardly visible in the elemental maps and therefore negligible. Image quantification was performed without internal standard correction since no element suitable as internal standard (i.e. constant concentration in whole sample) was available. Finding a way for utilizing internal standardization to compensate differences in material ablation and instrumental drifts could potentially further improve the accuracy of the analysis.

The LA-ICP-MS elemental maps ( $c f$. Fig. 2, 3, Tables 2 and 3) show high $\mathrm{Ca}$ and $\mathrm{P}$ concentrations $\left(c a .170 \mathrm{mg} \mathrm{g}^{-1}\right.$ and $75 \mathrm{mg}$ $\mathrm{g}^{-1}$, respectively) as well as significant $\mathrm{Na}, \mathrm{Mg}$, and $\mathrm{Zn}$ content (ca. $3 \mathrm{mg} \mathrm{g}^{-1}, 1.3 \mathrm{mg} \mathrm{g}^{-1}$, and $140 \mu \mathrm{g} \mathrm{g}^{-1}$, respectively) in the calcified zone of the sample. In case of $\mathrm{Zn}$, there is a significant enrichment in the tidemark zone (up to $c a .400 \mu \mathrm{g} \mathrm{g}^{-1}$ ) visible. In case of $\mathrm{Na}$, the map of the $41 \mu \mathrm{m}$ slice shows also a relatively high concentration in the hyaline cartilage area, which cannot be observed for the $15 \mu \mathrm{m}$ sample. Since a preablation step was performed for the later one (for cleaning purposes; see Experimental), the Na measured in the hyaline cartilage tissue of the $41 \mu \mathrm{m}$ slice probably originates from surface contaminations.

For the areas consisting of hyaline cartilage tissue, a relatively high S content (up to $12 \mathrm{mg} \mathrm{g}^{-1}$ ) can be observed. Despite $\mathrm{S}$ being a main constituent, the image quality is rather poor, which is caused by the relatively high ionization energy of $\mathrm{S}$, the fact that the main $\mathrm{S}$ isotope $\left({ }^{32} \mathrm{~S}\right)$ cannot be measured due to polyatomic interferences $\left(\mathrm{O}_{2}^{+}\right.$species), and a relatively high Sbackground caused by the applied ablation chamber and tubing system. Beside S also K can predominately be observed in the hyaline cartilage tissue $\left(0.2-1.5 \mathrm{mg} \mathrm{g}^{-1}\right)$. Even though the measurement of $\mathrm{K}$ suffers from a high background due to interferences originating from the plasma gas $\left({ }^{38} \mathrm{Ar}^{1} \mathrm{H}^{+}\right)$, the quality of the obtained images is sufficient.

\section{Method correlation}

Since every analytical technique has certain requirements to the samples, the first challenge was to choose a sample preparation approach compatible with both imaging methods. In our experiments, PMMA embedding resulted in self-supporting thin sections, which allowed direct analysis with $\mu \mathrm{XRF}$; and 
acrylic glass frames ensured that the sample is flattened during the measurement. After the non-destructive $\mu \mathrm{XRF}$ measurements, an intact sample was transferred to LA-ICP-MS instrument. For LA-ICP-MS measurements sample was glued onto a plastic slide using sticky tape on the edges of the sample similarly, to straighten and fix the sample horizontally; no other sample handling manipulations were required. While the method of PMMA embedding is routinely used in bone samples preparation, it is worth mentioning, that the preservation of hyaline cartilage in the same way might not be optimal and some elements (diffusible ions, like $\mathrm{Na}^{+}$and $\mathrm{K}^{+}$) might have been washed out or relocated. ${ }^{31}$ Further investigations and more refined sample preparation techniques (e.g. cryofixation/ freeze-drying) are needed to obtain the information on chemical distribution within the non-mineralized cartilage in nearnatural state.

Due to the non-destructive character of $\mu \mathrm{XRF}$, these measurements were performed first. An advantage of this experimental order is that $\mu \mathrm{XRF}$ results provide guidance for the elements of interest in subsequent LA-ICP-MS analysis. In our experiments we first focused on the expected major elements, which could be measured by both $\mu$ XRF and LA-ICP-MS. In addition LA-ICP-MS provided the images for light metals - Na and $\mathrm{Mg}$, which could not be imaged by laboratory $\mu \mathrm{XRF}$ due to limitations of the measuring system (e.g. detector window transmission).

We obtained quantitative maps with both methods, the employed quantification approach resulted in the

Table $215 \mu \mathrm{m}$ slice - comparison of elemental concentrations in mineralized and cartilage (hyaline) areas by average values and associated standard deviations $(\bar{x} \pm s)$

\begin{tabular}{|c|c|c|}
\hline \multirow[b]{3}{*}{$15 \mu \mathrm{m}$} & \multicolumn{2}{|c|}{ Mineralized tissue $\left(\mathrm{Ca}(\mathrm{XRF})>100 \mathrm{mg} \mathrm{g}^{-1}\right)$} \\
\hline & LA-ICP-MS & $\mu \mathrm{XRF}$ \\
\hline & $\bar{x} \pm s$ & $\bar{x} \pm s$ \\
\hline $\mathrm{Ca}$ & $171 \pm 77 \mathrm{mg} \mathrm{g}^{-1}$ & $137 \pm 19 \mathrm{mg} \mathrm{g}^{-1}$ \\
\hline $\mathrm{K}$ & $<\mathrm{LOD}$ & - \\
\hline $\mathrm{Mg}$ & $1.3 \pm 0.6 \mathrm{mg} \mathrm{g}^{-1}$ & - \\
\hline $\mathrm{Na}$ & $3 \pm 1.4 \mathrm{mg} \mathrm{g}^{-1}$ & - \\
\hline $\mathrm{P}$ & $77 \pm 36 \mathrm{mg} \mathrm{g}^{-1}$ & $90 \pm 13 \mathrm{mg} \mathrm{g}^{-1}$ \\
\hline $\mathrm{S}$ & $<$ LOQ & - \\
\hline \multirow[t]{3}{*}{$\mathrm{Zn}$} & $139 \pm 115 \mu \mathrm{g} \mathrm{g}^{-1}$ & $12 \pm 17 \mu g^{-1}$ \\
\hline & \multicolumn{2}{|c|}{ Cartilage (hyaline) $\left(\mathrm{S}(\mathrm{XRF})>10 \mathrm{mg} \mathrm{g}^{-1}\right)$} \\
\hline & LA-ICP-MS & $\mu \mathrm{XRF}$ \\
\hline $15 \mu \mathrm{m}$ & $\bar{x} \pm s$ & $\bar{x} \pm s$ \\
\hline $\mathrm{Ca}$ & $3.5 \pm 1.6 \mathrm{mg} \mathrm{g}^{-1}$ & $2.6 \pm 5.6 \mathrm{mg} \mathrm{g}^{-1}$ \\
\hline $\mathrm{K}$ & $<$ LOQ & - \\
\hline $\mathrm{Mg}$ & $194 \pm 76 \mu \mathrm{g} \mathrm{g}^{-1}$ & - \\
\hline $\mathrm{Na}$ & $100 \pm 42 \mu \mathrm{g} \mathrm{g}^{-1}$ & - \\
\hline $\mathrm{P}$ & $<$ LOD & $1.4 \pm 3.5 \mathrm{mg} \mathrm{g}^{-1}$ \\
\hline $\mathrm{S}$ & $6 \pm 1.9 \mathrm{mg} \mathrm{g}^{-1}$ & $17 \pm 3.5 \mathrm{mg} \mathrm{g}^{-1}$ \\
\hline $\mathrm{Zn}$ & $7 \pm 4 \mu \mathrm{g} \mathrm{g}^{-1}$ & $1 \pm 4 \mu g g^{-1}$ \\
\hline
\end{tabular}

Table $341 \mu \mathrm{m}$ slice - comparison of elemental concentrations in mineralized and cartilage (hyaline) areas by average values and associated standard deviations $(\bar{x} \pm s)$

\begin{tabular}{|c|c|c|}
\hline \multirow[b]{3}{*}{$41 \mu \mathrm{m}$} & \multicolumn{2}{|c|}{ Mineralized tissue $\left(\mathrm{Ca}(\mathrm{XRF})>100 \mathrm{mg} \mathrm{g}^{-1}\right)$} \\
\hline & LA-ICP-MS & $\mu \mathrm{XRF}$ \\
\hline & $\bar{x} \pm s$ & $\bar{x} \pm s$ \\
\hline $\mathrm{Ca}$ & $162 \pm 68 \mathrm{mg} \mathrm{g}^{-1}$ & $193 \pm 45 \mathrm{mg} \mathrm{g}^{-1}$ \\
\hline $\mathrm{K}$ & $<\mathrm{LOQ}$ & - \\
\hline $\mathrm{Mg}$ & $1.5 \pm 0.6 \mathrm{mg} \mathrm{g}^{-1}$ & - \\
\hline $\mathrm{Na}$ & $3.5 \pm 1.3 \mathrm{mg} \mathrm{g}^{-1}$ & - \\
\hline $\mathrm{P}$ & $72 \pm 31 \mathrm{mg} \mathrm{g}^{-1}$ & $102 \pm 25 \mathrm{mg} \mathrm{g}^{-1}$ \\
\hline $\mathrm{S}$ & $<\mathrm{LOQ}$ & - \\
\hline \multirow[t]{3}{*}{$\mathrm{Zn}$} & $145 \pm 68 \mu \mathrm{g} \mathrm{g}^{-1}$ & $94 \pm 32 \mu \mathrm{g} \mathrm{g}^{-1}$ \\
\hline & \multicolumn{2}{|c|}{ Cartilage (hyaline) $\left(\mathrm{S}(\mathrm{XRF})>10 \mathrm{mg} \mathrm{g}^{-1}\right.$ ) } \\
\hline & LA-ICP-MS & $\mu \mathrm{XRF}$ \\
\hline $41 \mu \mathrm{m}$ & $\bar{x} \pm s$ & $\bar{x} \pm s$ \\
\hline $\mathrm{Ca}$ & $7 \pm 30 \mathrm{mg} \mathrm{g}^{-1}$ & $8 \pm 23 \mathrm{mg} \mathrm{g}^{-1}$ \\
\hline $\mathrm{K}$ & $1 \pm 0.4 \mathrm{mg} \mathrm{g}^{-1}$ & $1.3 \pm 0.5 \mathrm{mg} \mathrm{g}^{-1}$ \\
\hline $\mathrm{Mg}$ & $174 \pm 193 \mu \mathrm{g} \mathrm{g}^{-1}$ & - $\quad 00$ \\
\hline $\mathrm{Na}$ & $1.5 \pm 0.7 \mathrm{mg} \mathrm{g}^{-1}$ & - \\
\hline $\mathrm{P}$ & $2.3 \pm 14 \mathrm{mg} \mathrm{g}^{-1}$ & $3.9 \pm 12.5 \mathrm{mg} \mathrm{g}^{-1}$ \\
\hline S & $5.9 \pm 2.2 \mathrm{mg} \mathrm{g}^{-1}$ & $27 \pm 6.7 \mathrm{mg} \mathrm{g}^{-1}$ \\
\hline $\mathrm{Zn}$ & $42 \pm 34 \mu \mathrm{g} \mathrm{g}^{-1}$ & $17 \pm 22 \mu \mathrm{g} \mathrm{g}^{-1}$ \\
\hline
\end{tabular}

concentrations in the same order of magnitude for the investigated elements imaged by both $\mu \mathrm{XRF}$ and LA-ICP-MS. To directly compare the elemental concentrations obtained by $\mu \mathrm{XRF}$ and LA-ICP-MS within the very same areas imaged by both techniques, we subdivided the maps shown in Fig. 2 and 3 in two subsections - mineralized tissue (selection criteria: Ca value in $\mu \mathrm{XRF}$ map $>100 \mathrm{mg} \mathrm{g}^{-1}$ ) and hyaline cartilage (selection criteria: $S$ value in $\mu$ XRF map $>10 \mathrm{mg} \mathrm{g}^{-1}$ ). The averaged values and standard deviation for the elements within these subsections are presented in Table $2(15 \mu \mathrm{m}$ slice $)$ and Table $3(41 \mu \mathrm{m}$ slice).

Generally for $\mu \mathrm{XRF}$, it should be noted that the excited/ detected sample mass in $15 \mu \mathrm{m}$ is lower than in $41 \mu \mathrm{m}$, which leads to different concentration values. As LA-ICP-MS is not affected by sample thickness, similar values are observed for 15 $\mu \mathrm{m}$ and $41 \mu \mathrm{m}$ slices, except for $\mathrm{K}$ - which is notably higher in the $41 \mu \mathrm{m}$ slice. Specifically for $\mathrm{K}$, it should be emphasized, that this element could be detected by $\mu \mathrm{XRF}$ only in the $41 \mu \mathrm{m}$ slice in cartilage - here we assume the influence of larger sampling volume in thicker sample. The $\mu \mathrm{XRF}$ mean cartilage value for potassium corresponds to the potassium content reported by LA-ICP-MS.

Since $S$ maps are more detailed in $\mu \mathrm{XRF}$ measurements, we conclude that LA-ICP-MS is less sensitive to S, most likely due to the previously mentioned high S-background ( $c f$. the estimated detection limits included in ESI, Table S5 $\dagger$ ). In case of Zn, LAICP-MS provided more detailed distribution maps for both samples - more features can be seen in slice $15 \mu \mathrm{m}$ in 
Table 4 Pearson correlation coefficients for analytes mapped with both techniques

\begin{tabular}{llr}
\hline & $\mu$ XRF vs. LA-ICP-MS & \\
\cline { 2 - 3 } Element & $15 \mu \mathrm{m}$ & $41 \mu \mathrm{m}$ \\
\hline $\mathrm{Ca}$ & 0.860 & 0.891 \\
$\mathrm{P}$ & 0.866 & 0.896 \\
$\mathrm{~S}$ & 0.698 & 0.840 \\
$\mathrm{Zn}$ & 0.427 & 0.740 \\
$\mathrm{~K}^{a}$ & - & -0.076
\end{tabular}

${ }^{a}$ Since $\mathrm{K}$ was not detected by $\mu \mathrm{XRF}$ in $15 \mu \mathrm{m}$ slice, no value is given for this sample.

comparison to $\mu \mathrm{XRF}$; in slice $41 \mu \mathrm{m}$ the histological structures are clearer, due to higher depth resolution of LA-ICP-MS.

To further evaluate the agreement between the images obtained by $\mu \mathrm{XRF}$ and LA-ICP-MS, we calculated the correlation between the corresponding elemental maps on Fig. 2 and 3. We used the Pearson correlation coefficient for the evaluation. It assumes values in the range from -1 to +1 , where 1 indicates strongest possible agreement, 0 strongest possible disagreement, and -1 perfect negative correlation. Table 4 displays the result - Pearson correlation coefficients calculated for each analyte obtained by $\mu$ XRF and LA-ICP-MS. Overall, lower coefficients were obtained for $15 \mu \mathrm{m}$ compared to $41 \mu \mathrm{m}$ sample. In case of $\mathrm{Ca}$ and $\mathrm{P}$, the method shows excellent agreement with high correlation coefficients for both samples. Also for S and $\mathrm{Zn}$ strong correlations can be observed, especially in $41 \mu \mathrm{m}$ slice. The only analyte showing poor correlation is $\mathrm{K}$. The reason for that is imperfect $\mu \mathrm{XRF}$ spectra fitting, leading to false-positive $\mathrm{K}$ distribution in calcified zone (see above), ultimately resulting in mismatched elemental map and, consequently, poor correlation. With the exception of $\mathrm{K}$, the correlation analysis confirms that the $\mu \mathrm{XRF}$ and LA-ICP-MS images are in good agreement.

Although many studies have been published on elemental distribution analyses of human bone with XRF-based methods, we were unable to find reports on quantitative mapping (absolute quantification). Papers on quantitative imaging with use of LA-ICP-MS exist, albeit limited to archaeological objects. ${ }^{32,33}$

Quantitative elemental analysis of bone will be of interest for the diagnostic reasons, for example, investigation of $\mathrm{Sr}$ incorporation from strontium ranelate with implications for the quality of the mineral crystal $;^{34}$ quantification of trace element accumulations $(\mathrm{Zn})$ in the tumorous tissue ${ }^{3}$ or estimation of metal transfer from orthopaedic implants. ${ }^{35}$ We have recently reported accumulations of elements-xenobiotics, e.g. lead in tidemark ${ }^{8}$ and gadolinium in bone, ${ }^{36}$ and quantification could help in assessing the risk of potential re-release of those elements in bloodstream.

As for rather neglected area of cartilage analysis, most of the elemental imaging experiments with LA-ICP-MS or $\mu$ XRF found in literature were performed qualitatively on the animal tissues. This limits the direct comparison to our results; nonetheless, these published findings point out other chemical elements, which should be considered in future measurements. Sussulini et al. imaged bovine cartilage by means of LA-ICP-MS, and in addition to $\mathrm{Na}, \mathrm{Mg}, \mathrm{P}, \mathrm{S}, \mathrm{K}, \mathrm{Ca}$, and $\mathrm{Zn}$, also $\mathrm{C}, \mathrm{Cl}$, Ti and $\mathrm{Cu}$ were detected in articular cartilage tissues. ${ }^{37}$ Whereas $\mathrm{C}$ and $\mathrm{Cl}$ are expected as intrinsic components of biological tissues, $\mathrm{Ti}$ is normally not present in cartilage and in our sample $(41 \mu \mathrm{m})$ was considered as contamination. $\mathrm{Cu}$, however, is an essential element and was also detected and imaged in dried droplet of synovial fluid of osteoarthritic patient by Austin et al. ${ }^{38}$ The authors also report distribution of $\mathrm{Ca}, \mathrm{P}, \mathrm{Mg}, \mathrm{Sr}$ and $\mathrm{Zn}$ in a knee cartilage section of OA patient. Notably, Austin et al. used thin samples for the experiments - dried $14 \mu \mathrm{m}$ sections, without any other treatment - which seemingly resulted in folding and twisting of the tissue. In our study, we observed only few cartilage folds in the thinner, $15 \mu \mathrm{m}$ sample, otherwise PMMA embedding facilitated preserving the overall shape of the tissue.

Reinert et al. obtained distributions of $\mathrm{P}, \mathrm{S}, \mathrm{Cl}, \mathrm{K}$ and $\mathrm{Ca}$ in articular cartilage of juvenile pig's knee joint using particle induced X-ray emission (PIXE) ${ }^{39}$ They reported variations in $\mathrm{S}$ distribution within different histological zones, consistent with proteoglycan content, positively correlated with $\mathrm{K}$, and displaying maximum concentration in hypertrophic cartilage (zone of hyaline cartilage contiguous to tidemark). Further, Reinert et al. detected calcium-phosphorus accumulation within the superficial cartilage. None of these was observed in our experiments. These dissimilarities could be attributed to the origin of the sample - animal vs. human; or the sample preparation freeze-drying by Reinert et al. and PMMA embedding in our case.

In future, adding histological analysis for detailed assignment of the cartilaginous zones and coupling elemental imaging with molecular (e.g. MALDI) could be beneficial. Human bone sample preparation allowing preservation of biomolecules (lipids) followed by consecutive time-of-flight secondary ion mass spectrometry (TOF-SIMS) and atmospheric pressure scanning microprobe matrix assisted laser desorption/ionization (AP-SMALDI) molecular imaging have been recently presented by Schaepe et $a .^{40}$ Knowledge on distributions and content of certain elements in human tissues will further histopathological studies. For instance, the elemental imaging of bone and cartilage will be of use for investigation of Ca deposits and crystals in cartilage, as well as osteoarthritic lesions. ${ }^{\mathbf{4 1 , 4 2}}$

The presented spatial distribution of elements accompanied by absolute quantitative data is an exceptional combination in human bone and cartilage analysis, and we hope that our research will serve as a base for future studies in this area.

\section{Conclusions}

The current paper presents the analysis by two elemental imaging techniques - $\mathrm{XXRF}$ and LA-ICP-MS - of a complex human bone-cartilage sample (femoral head). The measurements were performed in consecutive manner on the very same sample surfaces of two slices. Quantitative distribution mapping for both $\mu$ XRF and LA-IPC-MS was performed with the use of matrix-matched standards, and the concentrations obtained by both methods are either similar or at least in the same 
order of magnitude. We report concentrations for various elements within different histological zones - e.g. mineralized tissues, tidemark, hyaline cartilage. Further, we compared LAICP-MS and $\mu \mathrm{XRF}$ by means of correlation analysis applied to elemental maps, and observed strong (Ca, P in both samples, and $\mathrm{S}, \mathrm{Zn}$ in $41 \mu \mathrm{m}$ slice) or good ( $\mathrm{S}$ and $\mathrm{Zn}$ in $15 \mu \mathrm{m}$ slice) correlation of the methods. We believe that this is the first holistic description - imaging of elemental distribution supported by quantitative data - of bone and cartilage by either of the methods. Combined sequential application of $\mu$ XRF and LAICP-MS within one sample offers additional benefits, and should be further applied in the biomedical research.

\section{Conflicts of interest}

There are no conflicts of interest to declare

\section{Acknowledgements}

Authors thank Prof. Heinrich W Thaler for providing the samples. Authors would like to thank Dr Stéphane Blouin for support and EDX analysis of sample preparation tools, and technicians of LBIO for careful sample preparation. Authors gratefully acknowledge the help provided by Angelica de Leon (for cartilage preparation and characterization by XRF), Lukas Fenninger (for XRF measurements of cartilage pellets), Alexander Kleeweiss (for XRF measurements of cartilage pellets, fused beads), and Maximilian Bonta (for running trial test on a sample with LA-ICP-MS). AT and MR were supported by the FWF (The Austrian Science Fund) Project P 27715. AT also received support within MEIBio (Molecular and Elemental Imaging in Biosciences) PhD program of TU Wien. The authors acknowledge TU Wien Bibliothek for financial support through its Open Access Funding Programme.

\section{References}

1 D. S. Gholap, A. Izmer, B. De Samber, J. T. van Elteren, V. S. Šelih, R. Evens, K. De Schamphelaere, C. Janssen, L. Balcaen, I. Lindemann, L. Vincze and F. Vanhaecke, Comparison of laser ablation-inductively coupled plasmamass spectrometry and micro-X-ray fluorescence spectrometry for elemental imaging in Daphnia magna, Anal. Chim. Acta, 2010, 664, 19-26.

2 A. Al-Ebraheem, K. Geraki, R. Leek, A. L. Harris and M. J. Farquharson, The use of bio-metal concentrations correlated with clinical prognostic factors to assess human breast tissues, X-Ray Spectrom., 2013, 42, 330-336.

3 M. Rauwolf, B. Pemmer, A. Roschger, A. Turyanskaya, S. Smolek, A. Maderitsch, P. Hischenhuber, M. Foelser, R. Simon, S. Lang, S. E. Puchner, R. Windhager, K. Klaushofer, P. Wobrauschek, J. G. Hofstaetter, P. Roschger and C. Streli, Increased zinc accumulation in mineralized osteosarcoma tissue measured by confocal synchrotron radiation micro X-ray fluorescence analysis, $X$ Ray Spectrom., 2017, 46, 56-62.
4 A. Gaál, G. Orgován, V. G. Mihucz, I. Pape, D. Ingerle, C. Streli and N. Szoboszlai, Metal transport capabilities of anticancer copper chelators, J. Trace Elem. Med. Biol., 2018, 47, 79-88.

5 B. Pemmer, A. Roschger, A. Wastl, J. G. Hofstaetter, P. Wobrauschek, R. Simon, H. W. Thaler, P. Roschger, K. Klaushofer and C. Streli, Spatial distribution of the trace elements zinc, strontium and lead in human bone tissue, Bone, 2013, 57, 184-193.

6 A. Turyanskaya, M. Rauwolf, T. Grünewald, M. Meischel, S. Stanzl-Tschegg, J. Löffler, P. Wobrauschek, A. Weinberg, H. Lichtenegger and C. Streli, $\mu$ XRF Elemental Mapping of Bioresorbable Magnesium-Based Implants in Bone, Materials, 2016, 9, 811.

7 N. Zoeger, C. Streli, P. Wobrauschek, C. Jokubonis, G. Pepponi, P. Roschger, J. Hofstaetter, A. Berzlanovich, D. Wegrzynek, E. Chinea-Cano, A. Markowicz, R. Simon and G. Falkenberg, Determination of the elemental distribution in human joint bones by SR micro XRF, X-Ray Spectrom., 2008, 37, 3-11.

8 A. Roschger, J. G. Hofstaetter, B. Pemmer, N. Zoeger, P. Wobrauschek, G. Falkenberg, R. Simon, A. Berzlanovich, H. W. Thaler, P. Roschger, K. Klaushofer and C. Streli, Differential accumulation of lead and zinc in doubletidemarks of articular cartilage, Osteoarthritis and Cartilage, 2013, 21, 1707-1715.

9 N. Zoeger, P. Roschger, J. G. Hofstaetter, C. Jokubonis, G. Pepponi, G. Falkenberg, P. Fratzl, A. Berzlanovich, W. Osterode, C. Streli and P. Wobrauschek, Lead accumulation in tidemark of articular cartilage, Osteoarthritis and Cartilage, 2006, 14, 906-913.

10 K. Geraki, M. J. Farquharson, D. A. Bradley, O. Gundogdu and G. Falkenberg, The localisation of biologically important metals in soft and calcified tissues using a synchrotron x-ray fluorescence technique, X-Ray Spectrom., 2008, 37, 12-20.

11 A. Boyde, F. A. Mccorkell, G. K. Taylor, R. J. Bomphrey and M. Doube, Iodine vapor staining for atomic number contrast in backscattered electron and X-ray imaging, Microsc. Res. Tech., 2014, 77, 1044-1051.

12 B. Pouran, V. Arbabi, A. G. Bajpayee, J. van Tiel, J. Töyräs, J. S. Jurvelin, J. Malda, A. A. Zadpoor and H. Weinans, Multi-scale imaging techniques to investigate solute transport across articular cartilage, J. Biomech., 2018, 78, 10-20.

13 A. Limbeck, P. Galler, M. Bonta, G. Bauer, W. Nischkauer and F. Vanhaecke, Recent advances in quantitative LA-ICPMS analysis: Challenges and solutions in the life sciences and environmental chemistry ABC Highlights: Authored by Rising Stars and Top Experts, Anal. Bioanal. Chem., 2015, 407, 6593-6617.

14 R. Zhang, L. Li, Y. Sultanbawa and Z. P. Xu, X-ray fluorescence imaging of metals and metalloids in biological systems, Am. J. Nucl. Med. Mol. Imagingc, 2018, 8, 169-188.

15 D. S. Urgast, J. H. Beattie and J. Feldmann, Imaging of trace elements in tissues: With a focus on laser ablation 
inductively coupled plasma mass spectrometry, Curr. Opin. Clin. Nutr. Metab. Care, 2014, 17, 431-439.

16 D. Pozebon, G. L. Scheffler and V. L. Dressler, Recent applications of laser ablation inductively coupled plasma mass spectrometry (LA-ICP-MS) for biological sample analysis: A follow-up review, J. Anal. At. Spectrom., 2017, 32, 890-919.

17 K. M. Davies, D. J. Hare, S. Bohic, S. A. James, J. L. Billings, D. I. Finkelstein, P. A. Doble and K. L. Double, Comparative Study of Metal Quantification in Neurological Tissue Using Laser Ablation-Inductively Coupled PlasmaMass Spectrometry Imaging and X-ray Fluorescence Microscopy, Anal. Chem., 2015, 87, 6639-6645.

18 J.-C. Müller, M. Horstmann, L. Traeger, A. U. Steinbicker, M. Sperling and U. Karst, $\mu$ XRF and LA-ICP-TQMS for quantitative bioimaging of iron in organ samples of a hemochromatosis model, J. Trace Elem. Med. Biol., 2019, 52, 166-175.

19 A. Balbekova, M. Bonta, S. Török, J. Ofner, B. Döme, A. Limbeck and B. Lendl, FTIR-spectroscopic and LA-ICPMS imaging for combined hyperspectral image analysis of tumor models, Anal. Methods, 2017, 9, 5464-5471.

20 M. Holzlechner, M. Bonta, H. Lohninger, A. Limbeck and M. Marchetti-Deschmann, Multisensor Imaging - From Sample Preparation to Integrated Multimodal Interpretation of LA-ICPMS and MALDI MS Imaging Data, Anal. Chem., 2018, 90, 8831-8837.

21 A. Svirkova, A. Turyanskaya, L. Perneczky, C. Streli and M. Marchetti-Deschmann, Multimodal imaging of undecalcified tissue sections by MALDI MS and $\mu \mathrm{XRF}$, Analyst, 2018, 143, 2587-2595.

22 S. Blouin, H. W. Thaler, C. Korninger, R. Schmid, J. G. Hofstaetter, R. Zoehrer, R. Phipps, K. Klaushofer, P. Roschger and E. P. Paschalis, Bone matrix quality and plasma homocysteine levels, Bone, 2009, 44, 959-964.

23 P. Roschger, P. Fratzl, J. Eschberger and K. Klaushofer, Validation of quantitative backscattered electron imaging for the measurement of mineral density distribution in human bone biopsies, Bone, 1998, 23, 319-326.

24 S. Smolek, B. Pemmer, M. Fölser, C. Streli and P. Wobrauschek, Rev. Sci. Instrum., 2012, 83, 083703.

25 International Atomic Energy Agency (IAEA), 2009, https:// www.iaea.org/publications/7884/quantitative-x-ray-analysissystem.

26 L. Perneczky, Implementation of a confocal synchrotron radiation induced micro X-ray fluorescence system for bone analysis at the X-ray fluorescence beamline of ELETTRA synchrotron, Master's thesis, TU Wien, 2018. http://hdl.handle.net/20.500.12708/3465.

27 C. A. Schneider, W. S. Rasband and K. W. Eliceiri, NIH Image to ImageJ: 25 years of image analysis, Nat. Methods, 2012, 9, 671-675.

28 V. Pichler, Ansätze zur Quantifizierung in der Mikro-XRFAnalyse unter Verwendung eines speziellen Spektrometers für leichte Elemente, Master's thesis, TU Wien, 2019, http://hdl.handle.net/20.500.12708/2013.
29 J. H. Hubbell and S. M. Seltzer, Tables of X-Ray Mass Attenuation Coefficients and Mass Energy-Absorption Coefficients from $1 \mathrm{keV}$ to $20 \mathrm{MeV}$ for Elements $\mathrm{Z}=1$ to 92 and 48 Additional Substances of Dosimetric Interest. XRay Mass Attenuation Coefficients, NIST Standard Reference Database, https://physics.nist.gov/PhysRefData/ XrayMassCoef/tab4.html.

30 D. R. White, J. Booz, R. V. Griffith, J. J. Spokas and I. J. Wilson, Report 44, Tissue substitutes in radiation dosimetry and measurement, 1989, vol. os23.

31 M. J. Hackett, J. A. McQuillan, F. El-Assaad, J. B. Aitken, A. Levina, D. D. Cohen, R. Siegele, E. A. Carter, G. E. Grau, N. H. Hunt and P. A. Lay, Chemical alterations to murine brain tissue induced by formalin fixation: implications for biospectroscopic imaging and mapping studies of disease pathogenesis, Analyst, 2011, 136, 2941.

32 A.-F. Maurer, P. Barrulas, A. Person, J. Mirão, C. Barrocas Dias, O. Boudouma and L. Segalen, Testing LA-ICP-MS analysis of archaeological bones with different diagenetic histories for paleodiet prospect, Palaeogeogr., Palaeoclimatol., Palaeoecol., 2019, 534, 109287.

33 K. L. Rasmussen, G. Milner, L. Skytte, N. Lynnerup, J. L. Thomsen and J. L. Boldsen, Mapping diagenesis in archaeological human bones, Heritage Sci., 2019, 7, 41.

34 C. Li, O. Paris, S. Siegel, P. Roschger, E. P. Paschalis, K. Klaushofer and P. Fratzl, Strontium is incorporated into mineral crystals only in newly formed bone during strontium ranelate treatment, J. Bone Miner. Res., 2010, 25, 968-975.

35 F. Bilo, L. Borgese, J. Prost, M. Rauwolf, A. Turyanskaya, P. Wobrauschek, P. Kregsamer, C. Streli, U. Pazzaglia and L. E. Depero, Atomic layer deposition to prevent metal transfer from implants: An X-ray fluorescence study, Appl. Surf. Sci., 2015, 359, 215-220.

36 A. Turyanskaya, M. Rauwolf, V. Pichler, R. Simon, M. Burghammer, O. J. L. Fox, K. Sawhney, J. G. Hofstaetter, A. Roschger, P. Roschger, P. Wobrauschek and C. Streli, Detection and imaging of gadolinium accumulation in human bone tissue by micro- and submicro-XRF, Sci. Rep., 2020, 10, 6301.

37 A. Sussulini, E. Wiener, T. Marnitz, B. Wu, B. Müller, B. Hamm and J. Sabine Becker, Quantitative imaging of the tissue contrast agent [Gd(DTPA)]2- in articular cartilage by laser ablation inductively coupled plasma mass spectrometry, Contrast Media Mol. Imaging, 2013, 8, 204-209.

38 C. Austin, D. Hare, A. L. Rozelle, W. H. Robinson, R. Grimm and P. Doble, Elemental bio-imaging of calcium phosphate crystal deposits in knee samples from arthritic patients, Metallomics, 2009, 1, 142.

39 T. Reinert, U. Reibetanz, M. Schwertner, J. Vogt, T. Butz and A. Sakellariou, The architecture of cartilage: Elemental maps and scanning transmission ion microscopy/tomography, Nucl. Instrum. Methods Phys. Res., Sect. B, 2002, 188, 1-8.

40 K. Schaepe, D. R. Bhandari, J. Werner, A. Henss, A. Pirkl, M. Kleine-Boymann, M. Rohnke, S. Wenisch, E. Neumann, J. Janek and B. Spengler, Imaging of Lipids in Native Human Bone Sections Using TOF-Secondary Ion Mass 
Spectrometry, Atmospheric Pressure Scanning Microprobe Matrix-Assisted Laser Desorption/Ionization Orbitrap Mass Spectrometry, and Orbitrap-Secondary Ion Mass Spectrometry, Anal. Chem., 2018, 90, 8856-8864.

41 W. Kaabar, O. Gundogdu, a. Laklouk, O. Bunk, F. Pfeiffer, M. J. Farquharson and D. a Bradley, Micro-PIXE and SAXS studies at the bone-cartilage interface, Appl. Radiat. Isot., 2010, 68, 730-734.

42 W. Kaabar, a. Laklouk, O. Bunk, M. Baily, M. J. Farquharson and D. Bradley, Compositional and structural studies of the bone-cartilage interface using PIXE and SAXS techniques, Nucl. Instrum. Methods Phys. Res., Sect. A, 2010, 619, 78-82. 